\title{
Transgender Rights in Accordance with Civil \& Sharia Law: Malaysia and Asean Perspectives
}

\author{
Wan Amir Azlan Wan Haniff , Siti Mariam Atan, Rahmawati Mohd Yusoff, \\ Rosnani Mohd Salleh, Zulhazmi Yusof
}

To Link this Article: http://dx.doi.org/10.6007/IJARBSS/v11-i3/8862

DOI:10.6007/IJARBSS/v11-i3/8862

Received: 16 January 2021, Revised: 20 February 2021, Accepted: 10 March2021

Published Online: 26 March 2021

In-Text Citation: (Haniff et al., 2021)

To Cite this Article: Haniff, W. A. A. W., Atan, S. M., Yusoff, R. M., Salleh, R. M., \& Yusof, Z. (2021). Transgender Rights in Accordance with Civil \& Sharia Law: Malaysia and Asean Perspectives. International Journal of Academic Research in Business and Social Sciences, 11(3), 1305-1320.

Copyright: (c) 2021 The Author(s)

Published by Human Resource Management Academic Research Society (www.hrmars.com)

This article is published under the Creative Commons Attribution (CC BY 4.0) license. Anyone may reproduce, distribute, translate and create derivative works of this article (for both commercial and non-commercial purposes), subject to full attribution to the original publication and authors. The full terms of this license may be seen

at: http://creativecommons.org/licences/by/4.0/legalcode

Vol. 11, No. 3, 2021, Pg. 1305 - 1320

Full Terms \& Conditions of access and use can be found at http://hrmars.com/index.php/pages/detail/publication-ethics 


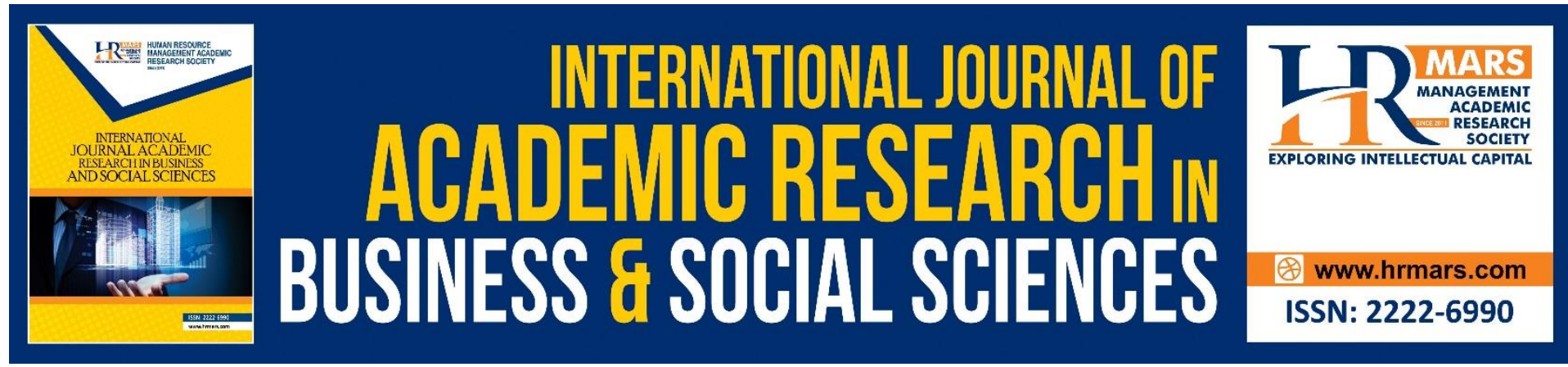

\title{
Transgender Rights in Accordance with Civil \& Sharia Law: Malaysia and Asean Perspectives
}

\author{
Wan Amir Azlan Wan Haniff a, Siti Mariam Atan ${ }^{\mathrm{b}}$, Rahmawati \\ Mohd Yusoff ${ }^{\mathrm{c}}$, Rosnani Mohd Salleh ${ }^{\mathrm{d}}$, Zulhazmi Yusof ${ }^{\mathrm{e}}$ \\ aSenior Lecturer, Department of Law, Universiti Teknologi Mara Kampus Segamat, 85000 \\ Segamat, Johor, Malaysia, 'benior Lecturer, Department of Law, Universiti Teknologi Mara \\ Kampus Segamat, 85000 Segamat, Johor, Malaysia, 'Senior Lecturer, Department of Law, \\ Universiti Teknologi Mara Kampus Segamat, 85000 Segamat, Johor, Malaysia, dSenior \\ Lecturer, Department of Law, Universiti Teknologi Mara Kampus Segamat, 85000 Segamat, \\ Johor, Malaysia, eLecturer, Department of Law, Universiti Teknologi Mara Kampus Segamat, \\ 85000 Segamat, Johor, Malaysia \\ Email:wamirazlan@uitm.edu.my,sitim223@uitm.edu.my,rahmawatimy@uitm.edu.my, \\ rosna243@uitm.edu.my, zulhazmi@uitm.edu.my
}

\begin{abstract}
Background: The transgender term is used to illustrate a broad-spectrum of identities and experiences, inclusive to pre-operative, post-operative, and non-operative transsexual people; male and female cross-dressers; intersexed individuals; and men and women, whose appearance or features are recognised to be gender atypical. Transgender people are often exposed to violence and legally sanctioned discriminant on a daily basis in Malaysia, but it does not prevent them from growing in number. Objective: This article analyses the legal rights of transgender in Malaysia based on civil and Sharia law available with reference to international and ASEAN perspectives in consideration of the possibility for crossjurisdictional study. Method: This qualitative research adopts primary and secondary data benefitted from scientific report analysis and literature including statutes, law cases \& papers on transgender. These details were analysed by legal interpretation and comparative assessment. Result: The research reveals that there is an absence of definition of transgender in any Malaysia legislation, but that does not prevent the transprejudice and legally sanctioned discriminant in every way possible e.g., men who appear as women. Still, with respect to healthcare settings, medical doctors in Malaysia conveyed relatively low intent to discriminate against transgender patients. In ASEAN perspective, notwithstanding the endorsement of ASEAN Human Rights Declaration, it lacks the capability to enforce its provisions in cases of transgression. Conclusion and recommendation: It is a long way off for Malaysia to recognise the rights of transgender due to the fact that the fundamental principles of the country mostly based on Sharia law and Islamic value. Nevertheless, there is path for intersex individual who according to Islamic jurists is not categorised as transgender, thus deserve to not be discriminated in all forms. Hence, the paper recommends Malaysian
\end{abstract}


authority to endeavour to thoroughly define transgender from both civil and Sharia law point of view.

Keywords: Human Rights, Civil law, Sharia law, ASEAN, International, AICHR

\section{Introduction}

Currah, Minter \& Green (2013) construed transgender as an "umbrella" term that accustomed to illustrate a broad-spectrum of identities and experiences, inclusive to preoperative, post-operative, and non-operative transsexual people; male and female crossdressers; intersexed individuals; and men and women, whose appearance or features are viewed to be gender atypical This term is distinct from sexual orientation (Gibson et al. 2016). While the former insert intersex individuals as a subset of transgender, Fiqh Jurists however have distinguished between intersex individuals and transgender. According to Malaysia Mufti of Federal Territory (2017), intersex individuals are asl al-khilqah (the original creation of God since he/she was born) while transsexual is taghyir al-khilqah (change God creation). Hence, intersex individuals are not considered as transgender. Fiqh Jurists completely defined transgender as a women who resembles as men or vice versa by way of clothing, adornment, speech and voice, gait and body movement and to the extent of changing one's physical body as well (Malaysia Mufti of Federal Territory, 2015).

In arabic term, transgender were known as tasyabbuh which means 'resembling something' (Kambol, 2020). After examining these definitions, one may conclude that in general, transgender people is individual who behave or identify himself/herself outside of stereotypical gender norms. It is worth highlighting that in Malaysia social-historical context, transgender woman (male-to-female) are known as mak nyah or pondan which is in fact a malay term that frequently used in an offensive way to refer to male-to-female transgenders or effeminate gay men, while transgender man (female-to-male) are identified as pengkid or tomboy (Mohamad, 2015).

The article analyses the legal rights of transgender people in Malaysia based on civil and Sharia law available with reference to international and ASEAN perspectives in consideration of the possibility for cross-jurisdictional study. This qualitative research adopts primary and secondary data benefited from scientific report analysis and literature including statutes, law cases \& papers on transgender. These details were analysed by legal interpretation and comparative assessment (Haniff, Hakimah \& Ismail, 2019). This article proceeds as follows. Part 2 of the article explore current scenario of transgender in Malaysia with reference to the position of civil and Sharia law. Part 3 and 4 of the article discusses the transgender rights based on international and Association of South East Asian Nations (ASEAN) perspectives. The article concludes by stressing the path for transgender people in Malaysia and provide recommendation to the Malaysian authority to acknowledge the rights of transgender people in the country.

\section{Current Scenario of Transgender in Malaysia}

Vijay et al. (2018) stated that the population of transgender people worldwide is vague, nonetheless, estimates indicate that worldwide $0.4 \%-1.2 \%$ of birth-assigned females and $0.5 \%-1.3 \%$ of birth-assigned males identify as transgender. Meanwhile, in Malaysia, Department of Islamic Development Malaysia has revealed that transgender people recorded an increase of 30,000 individuals in 2018 , compared to only 10,000 three (3) decades ago 
(Dermawan, 2018). Among factors contributing to the increase in transgender people in Malaysia is utilization of social media facilities which enables such exposure to young people (Khuhro \& Ahtisham, 2020; Harper et al., 2015).

Malaysia Department of Statistic (2019) exposed that as of second quarter 2019, there were approximately 32.58 million people in Malaysia with Islam as the most widely professed religion with the proportion of 61.3 per cent (Index Mundi, 2018). Understandably, the issue of discrimination, physical and mental violation toward transgender people are common as they are not generally accepted due to the fact that they are against the fundamental principles of the country which mostly based on sharia law and Islamic value. In additions, majority Muslims who holds Islamic values as their basic culture regulation view transgender as unusual and deviate. This is among the reason why Seksualiti Merdeka festival took place in which the aims were to introduce the life of lesbian, gay, bisexual and transgender (LGBT) people and its communities to the public as well as raising public awareness to not discriminate and intimidate sexual orientation minorities (Ar, 2013). Nonetheless, the festival was banned by the government in 2011.

Undoubtedly, the discrimination of right occurs because of the contradiction on human rights as defined by Universal Declaration of Human Rights (UDHR) with Malaysia civil and Sharia law. Pursuant to Article 2 UDHR, everyone is entitled to all the rights and freedoms set forth in this Declaration, without distinction of any kind which includes but not limited to sex, religion, birth or other status. Malaysian civil and Sharia law however, does not give protection to the people who engaged in homosexual conduct or transgenderism. Still, they are allowed to live, work, own property etc, but to express themselves publicly are considered offensive towards Malaysian society and such acts may classified as an offence under civil, criminal and Sharia law.

The different perspective between pro LGBT and anti LGBT movement has resulted to tension in the country to the extent of portrait of transgender activist named Nisha Ayub, who was awarded the US International Women of Courage award in 2016 for her work in combating the discrimination on transgender, was taken down in public photo exhibition to comply with the current government's policy of no promotion of LGBT culture (Loshana, Shagar, Zainal \& Loh, 2018). Clearly, even after new government take over for the first time after 60 years, there is no significant change in government policy when it comes to transgender rights. In fact, according to the then Minister of Religious Affairs, Dr Mujahid Yusof Rawa, government still refuse to recognise LGBT practices as lawful (Bernama, 2019).

Further, Malaysia government refused to fulfil demands from Coalition of Malaysian NGO's (COMANGO) ${ }^{1}$ in 2014 to ratify International Covenant on Civil and Political Rights (ICCPR) which instructs from the member states to safeguard to all citizens in their nation, and who are subject to their jurisdiction, the rights acknowledged in the Covenant without distinction to sex, religion, birth or other status (Hilmi, Salleh \& Rahman, 2019). Apart from ICCPR that had been denied by Malaysia government, other key international human rights

${ }^{1}$ COMANGO was established in 2008 with 54 organizations to provide a human rights report in Malaysia to be submitted to the United Nation (UN) Human Rights Council's Universal Periodic Review process under the UN in Geneva 
instruments conventions such as International Covenant on the Elimination of All Forms of Racial Discrimination (ICERD) and The International Covenant on Economic, Social and Cultural Rights (ICESCR) were also not entertained (Bernama, 2018). Obviously, the path for Malaysia government to promulgate laws banning discrimination on the basis of Sexual Orientation and Gender Identity (SOGI) which recognised the rights of transgender persons to have consented homosexual activity and same sex marriage as demanded by COMANGO is still a long way off.

Nevertheless, even though transgender people in Malaysia face such unfortunate prejudice, but in regards to healthcare settings, medical doctors in Malaysia conveyed relatively low intent to discriminate against transgender patients, although a minority of participants did express a moderate to high level of discriminatory intent (Vijay et al. 2018). This finding is important as it is critical to address health disparities for transgender people in order to improve the quality of healthcare they receive especially when they are at greater risk to be infected by Human Immunodeficiency Virus (HIV) and other Sexually Transmitted Infections. It could be proven when HIV prevalence for transgender women was $12.4 \%, 2$-fold higher than the $5.6 \%$ reported by the Malaysia Ministry of Health (Wickersham, 2017). Further, this finding may inform important directions for HIV prevention interventions among transgender women.

\section{Civil Law Position on Transgenderism}

It needs to be clear that the position of transgender people in legal aspect is still not recognized in civil or Sharia law in Malaysia. In fact, based on Section 27 Malaysia Births and Deaths Registration Act and Section 6(2)(o) National Registration Act, the legal gender of a person cannot be changed unless errors were made. This could be seen in the case of Tan Pooi Yee V. Director General of National Registration Department ([2016] 8 CL 427) when the plaintiff, who was biologically born as a woman, had successfully undergone gender reassignment surgery at a medical institution and had, post-surgery, undergone various psychological assessments and medical examinations by specialist medical practitioners, has applied for a declaration that 'he' is legally a male and for consequential orders to direct the defendant to recognize and set in place to such declaration. In this case, even though High Court awarded an originating summons and declaration filed by the plaintiff that she be asserted a man, but Court of Appeal set aside such order, thus prohibited a woman who underwent sex change to be recognised a man and to alter her identification card in order to ponder the male gender.

In addition to that, it worth revealing that under Section 21 of the Minor Offences Act 1955 , any person regardless of religion or race, still can be penalized for 'indecent behaviour' and be fined from MYR25 to MYR50. Since there is no clear definition of what constitutes as indecent behavior, the authority still can interpret transgenderism as indecent behavior. Unlike Sharia law which is only applied to Muslim, this law is applied to non-Muslim as well. Clearly, Malaysian civil law does not expressly and specifically mention on transgender.

It is noteworthy that transgender women are often associated with sexual activity with men due to similar biological risk (UNAIDS, 2014). Peletz (2006) however disagreed and argued that most transgender practices do not occasionally include abnormal sexual practices, however, the modern Malaysian state had occupied in institutionalizing "policies of heterosexism and homophobia" that have "had the effect of disciplining all individuals 
involved in transgenderism under Sharia law." As for civil law, there is a law for an offense of sexual acts committed by anyone including transgender under Sections 377A, 377B and 377C of Malaysian Penal Code. These provisions state the offenses and penalties on offenders who commit acts of sexual intercourse with other person by inserting the penis into the anus or mouth of another person. This person is said to engage unnatural carnal intercourse or buggery and according to section 377B Malaysia Penal Code, the punishment that will be imposed to whoever voluntarily commits such crimes are to be confined for a term which may be more to 20 years, and must also be punished with whipping. Meanwhile, Section 377c Malaysia Penal Code clearly stipulated the punishment if consent was absent where upon conviction, the offender will be punishable by imprisonment for a period not less than 5 years and not exceeding 20 years, and must also be punishable with whipping.

\section{Sharia Law Position on Transgender}

As mentioned above, there is no specific reference to civil law on transgender person who intentionally perceived to be gender atypical as the Penal Code only describing transgender offense of engaging in same-sex acts between men. However, this does not mean transgender person who are not committing such crime are freely to appear or behave against his/her biological gender especially when refer to Sharia law. Allah has created man in perfect form and has decided his gender identity on the basis of his sex, male or female, and is biologically congenital (Surah al-Shura, Al Quran 42: 49-50).

Regarding transgender issue, Afif (2019) declares that there is no specific explanation about transgender in the Holy Qur'an. However, the explanation of the issue is found in the tradition of the Prophet PBUH. There are several tradition of the Prophet PBUH on the issue. For example, al-Tabari, a well-known Muslim scholar explains that it is not permissible for men to imitate women in clothing and adornment that is exclusively for women such as their clothing and jewelry. It is also not permissible for women to imitate men while that is exclusively for men (Battal \& Khalaf, 2003). The imitation takes place in clothing, actions, and dwellings, and artificially formed parts, and voices. The clothing may differ according to the customs of country (Wuzarah al-Awqaf wa al-Shu'un al-Islamiyah, 1404-1427).

In Malaysia, 126th session of Malaysia Council of the Rulers which held on December 13, 1989 has declared that transgender practice is illegal to be adopted in a lifestyle. Furthermore, the National Fatwa Committee in April 1982 also ruled that once the person is born male, he will be regarded as male and same rule applies to those who are born as female, she will be regarded as female regardless whether they have or have not underwent reassignment surgery. Moreover, The National Fatwa Committee in October 2008 has ruled that tasyabbuh is forbidden (haram) and is among the major sins in Islam based on prophetic and Quranic evidences.

Muslim scholars are agreed on the prohibition of men who are in the imitate of women and those women who are in the imitate of men. Majority of the scholars view that it is totally prohibited (al-haram) and some of them view that the prohibition is disapproved (al-makruh). For example, a view in al-Shafi'i school of thought and views of some scholars in the Hanbali school of thought disapproved the intimation of men to women and vice versa as it is abominable (Wuzarah al-Awqaf wa al-Shu'un al-Islamiyah, 1404-1427).

It should be noted that Malaysia Sharia Courts (Criminal Jurisdiction) Act 1965 (Revised 1988) grants power to Sharia court to decide cases in relating to any Sharia offense including the offence of any men who appear as women. 
As a result of this provision, each state in Malaysia has jurisdiction to impose fine for an offence related to transgender based on several provisions under Sharia law in the Act or the Enactment or the State Criminal Offenses Ordinance in Malaysia. These provisions can be described as follows:

\begin{tabular}{|c|c|c|c|c|c|}
\hline State & $\begin{array}{l}\text { Act/Enactment/ } \\
\text { Ordinant }\end{array}$ & Section & Provision & $\begin{array}{l}\text { Fine } \\
\text { (MYR) }\end{array}$ & Imprisonment \\
\hline $\begin{array}{l}\text { Wilayah } \\
\text { Persekutua } \\
\mathrm{n}\end{array}$ & $\begin{array}{c}\text { Akta Kesalahan Jenayah } \\
\text { Syariah (Wilayah- } \\
\text { Wilayah Persekutuan) } \\
1997 .\end{array}$ & 28 & $\begin{array}{l}\text { Men who } \\
\text { appear as } \\
\text { women }\end{array}$ & $\leq 1000$ & $\leq 1$ Year \\
\hline Johor & $\begin{array}{c}\text { Enakmen Kesalahan } \\
\text { Jenayah Syariah (Johor) } \\
1997 .\end{array}$ & 28 & $\begin{array}{l}\text { Men who } \\
\text { appear as } \\
\text { women }\end{array}$ & $\leq 1000$ & $\leq 1$ Year \\
\hline Kedah & $\begin{array}{l}\text { Enakmen Kanun } \\
\text { Jenayah Syariah } 1988 \\
\text { Kedah. }\end{array}$ & 7 & Pondan & $\leq 1000$ & $\leq 6$ Bulan \\
\hline Kelantan & $\begin{array}{c}\text { Enakmen Kanun } \\
\text { Jenayah Syariah } 1985 \\
\text { Kelantan. }\end{array}$ & 7 & Pondan & $\leq 1000$ & $\leq 6$ Bulan \\
\hline Terengganu & $\begin{array}{c}\text { Enakmen Kesalahan } \\
\text { Jenayah Syariah } \\
\text { (Takzir)(Terengganu) } \\
2001 .\end{array}$ & 33 & $\begin{array}{l}\text { Men who } \\
\text { appear as } \\
\text { women }\end{array}$ & $\leq 1000$ & $\leq 1$ Year \\
\hline Melaka & $\begin{array}{c}\text { Enakmen Kesalahan } \\
\text { Syariah (Negeri Melaka) } \\
1991 .\end{array}$ & 72 & $\begin{array}{c}\text { Men who } \\
\text { appear as } \\
\text { women }\end{array}$ & $\leq 1000$ & $\leq 6$ Bulan \\
\hline $\begin{array}{c}\text { Negeri } \\
\text { Sembilan }\end{array}$ & $\begin{array}{l}\text { Enakmen Jenayah } \\
\text { Syariah Negeri } \\
\text { Sembilan } 1992 .\end{array}$ & 66 & $\begin{array}{l}\text { Men who } \\
\text { appear as } \\
\text { women }\end{array}$ & $\leq 1000$ & $\leq 6$ Bulan \\
\hline \multirow[t]{2}{*}{ Pahang } & \multirow[t]{2}{*}{$\begin{array}{c}\text { Enakmen Kesalahan } \\
\text { Jenayah (Pahang) } 2013\end{array}$} & 33 & $\begin{array}{c}\text { Men who } \\
\text { appear as } \\
\text { women }\end{array}$ & $\leq 1000$ & $\leq 1$ Year \\
\hline & & 34 & $\begin{array}{l}\text { Women } \\
\text { who } \\
\text { appear as } \\
\text { men }\end{array}$ & $\leq 1000$ & $\leq 1$ Year \\
\hline $\begin{array}{l}\text { Pulau } \\
\text { Pinang }\end{array}$ & $\begin{array}{c}\text { Enakmen Kesalahan } \\
\text { Jenayah Syariah (Negeri } \\
\text { Pulau Pinang) } 1996\end{array}$ & 28 & $\begin{array}{l}\text { Men who } \\
\text { appear as } \\
\text { women }\end{array}$ & $\leq 1000$ & $\leq 1$ Year \\
\hline Perak & $\begin{array}{c}\text { Enakmen Jenayah } \\
\text { (Syariah) } 1992 \text { Perak. }\end{array}$ & 55 & $\begin{array}{c}\text { Men who } \\
\text { appear as } \\
\text { women }\end{array}$ & $\leq 1000$ & $\leq 1$ Year \\
\hline Perlis & & 7 & Pondan & $\leq 5000$ & $\leq 3$ Year \\
\hline
\end{tabular}




\begin{tabular}{|c|c|c|c|c|c|}
\hline & $\begin{array}{c}\text { Enakmen Jenayah } \\
\text { Dalam Syarak 1991 } \\
\text { Perlis }\end{array}$ & $\begin{array}{c}\text { Pondan } \\
\text { (women } \\
\text { who } \\
\text { appear as } \\
\text { men) }\end{array}$ & $\leq 5000$ & $\leq 3$ Year \\
\hline Sabah & $\begin{array}{c}\text { Enakmen Kesalahan } \\
\text { Jenayah Syariah 1995 } \\
\text { Sabah. }\end{array}$ & 92 & $\begin{array}{c}\text { Men who } \\
\text { appear as } \\
\text { women } \\
\text { and vice } \\
\text { versa }\end{array}$ & $\leq 1000$ & $\leq 6$ Bulan \\
\hline Sarawak & $\begin{array}{c}\text { Ordinan kesalahan } \\
\text { Jenayah Syariah 2001. }\end{array}$ & 25 & $\begin{array}{c}\text { Men who } \\
\text { appear as } \\
\text { women }\end{array}$ & $\leq 1000$ & $\leq 1$ Year \\
\hline
\end{tabular}

Table 1: Transgender offence based on Sharia law in the Act or the Enactment or the State Criminal Offenses Ordinance in Malaysia

The existence of these provisions above has been questioned by transgender community. In the case of Muhamad Juzaili Mohd Khamis \& Ors V. State Government of Negeri Sembilan \& others, ([2015] 1 CLJ 954), the appellants claim that section 66 Sharia Criminal Code Enactment 1992 (Enactment) which grant power to the Negeri Sembilan religious authorities to impose penalty not exceeding MYR1,000 or to be put in jail for a term not exceeding six (6) months or both to any Muslim men who wear women's clothing or to act as woman is ultra vires to Articles 5(1) (right to live) , 8 (1) and (2) (equality), 9 (2) (right to move freely) \& 10 (1) (a) (right to expression) Federal Constitution. Although the appellants have been confirmed by psychiatrists and psychologists to be diagnosed with a medical condition known as Gender Identity Disorder (GID), the Federal Court which is the highest court in Malaysia overturn the decision made by Court of Appeal and held that the provision of the enactment were not in contravention of Federal Constitution. Evidently, Malaysia Federal Constitution which is the supreme law of the land does not recognize transgender or third gender position as well.

In addition to the above, any male person who has committed an offence of sodomy shall be guilty of a crime under Section 25 Sharia Criminal Offences (Federal Territories) Act 1997 which upon conviction, carries punishment a fine not more than MYR5,000 or to be confined for a term not more three (3) years or to whipping not more than six (6) strokes or to any combination thereof. Obviously, this provision overlap with Penal Code. It is worth to note that Section 26 Sharia Criminal Offences (Federal Territories) Act 1997 does not discriminate female person as they also could be accountable to a fine not more than MYR5,000 or to be imprisoned for a term not more than three (3) years or to whipping not over six (6) strokes or to any combination thereof if found guilty on committing musahaqah (sexual relations between female person). Mohamad (2015) summarizes the number of Sharia criminal offense that is enforced throughout Malaysia as of 2014. 


\begin{tabular}{|l|l|l|l|l|l|}
\hline No & $\begin{array}{l}\text { Type of } \\
\text { offense }\end{array}$ & $\mathbf{2 0 1 1}$ & $\mathbf{2 0 1 2}$ & $\mathbf{2 0 1 3}$ & $\mathbf{2 0 1 4}$ \\
\hline 1 & Sodomy & 0 & 0 & 1 & 2 \\
\hline 2 & Musahaqah & 6 & 3 & 0 & 4 \\
\hline 3 & $\begin{array}{l}\text { Men who } \\
\text { appear as } \\
\text { women }\end{array}$ & 131 & 199 & 97 & 123 \\
\hline & Total & 137 & 202 & 98 & 129 \\
\hline
\end{tabular}

Table 2: Sharia criminal offenses enforced throughout Malaysia

\section{Transgender Rights from International Perspective}

In international level, transgender people enjoys similar human rights as all individuals which include the right to non-discrimination. This foundation is preserved in several international instruments such as Universal Declaration of Human Rights (UDHR) (Article 2, 18 \& 19), International Covenant on Civil and Political Rights (ICPPR) (Article 26) and International Covenant on Economic, Social and Cultural Rights (ICESR) (Article 2) which provides a wide scope in its application. Specifically, everyone are equal before the law and meriting to every right and freedom, impartial to any kind which includes but not limited to sex and the law shall forbid such prejudice and pledge to every individual equal and adequate protection against discrimination.

In addition to that, Sustainable Development Goals (SDGs) that was agreed in 2015 and signed onto by 193 governments including Malaysia was actually based on single, guiding principle: to leave no one behind (Park \& Mendos, 2019). This principle impliedly constitute a mandate to all signatories states to take into consideration of LGBT people in their development efforts. Likewise, UN Secretary-General, Ban Ki Moon's believe that this vision could be realised if we reach all people regardless of their sexual orientation or gender identity (United Nations, 2016). Despite the existence of such instruments, transgender in countries throughout the world are still facing serious human rights abuses because of their gender identity or sexual orientation. This is among the reason why United Nations Human Rights Committee was established - to monitors implementation of the ICCPR by its State parties (United Nations Human Rights, nd).

The issue of LGBT rights regularly raised by Human Rights Committee. A decade of concluding observations proposes the need for enhancement. For instance, as stipulated by Gerber \& Gory (2014), the Human Rights Committee's inspections on areas in which a State Party could reform tended to fall into two (2) categories:

1) Anti-discrimination steps (namely the failure to forbid employment-related discrimination, the failure to provide the classification of sexual orientation in wide anti-discrimination legal frameworks, insufficient organisational measure to unfair attitudes and brutality as well as unequal ages of consent for sexual activity); and

2) the decriminalisation of homosexual activity.

Human Rights Committee (2017) suggested for Thailand to amend Gender Equality Act (2015) to eliminate any limitation on the protection against gender-based discrimination, 
(Section 17 of such act allows for exceptions to gender discrimination on grounds of religion and national security), for Vietnam to intensify its efforts to eliminate discrimination and brutality as well as social stigmatization of persons based on their gender identity (Human Rights Committee, 2019) and for Lao People's Democratic Republic to implement proactive anti-discrimination laws or policies (Human Rights Committee, 2018).

\section{Transgender Rights from Asean Perspective}

In ASEAN perspective, the human rights culture is not well developed compared to European countries (Nurhidayatuloh, Febrian, 2019). Most ASEAN countries consider that there is no essential priority to implement anti-discrimination regulation (Phan, 2019). Although several ASEAN countries are the parties to key international human rights instruments conventions such as ICCPR and ICESCR, these instruments fail to precisely include gender and sexual minorities as vulnerable groups, which than resulted to the failure in protecting them (Tahmindjis, 2005). Table 3 below shows ASEAN countries which have and have not ratified ICCPR and ICESCR.

\begin{tabular}{|l|l|l|}
\hline ASEAN Countries & ICCPR & ICESCR \\
\hline Malaysia & X & X \\
\hline Thailand & $\checkmark$ & $\checkmark$ \\
\hline Indonesia & $\checkmark$ & $\checkmark$ \\
\hline Brunei & $X$ & $X$ \\
\hline Philippines & $\checkmark$ & $\checkmark$ \\
\hline Singapore & $X$ & $X$ \\
\hline Myanmar & $X$ & $\checkmark$ \\
\hline Vietnam & $\checkmark$ & $\checkmark$ \\
\hline Laos & $\checkmark$ & $\checkmark$ \\
\hline Cambodia & $\checkmark$ & $\checkmark$ \\
\hline
\end{tabular}

Table 3: ASEAN countries which have and have not ratified ICCPR and ICESCR.

Previously, ASEAN did not take any actions to pursue the idea of a regional human rights mechanism despite the efforts to push forward such agenda attempted by Regional Working Group for an ASEAN Human Rights Mechanism. ASEAN is more focusing to be economic prosperity and it could be seen in ASEAN Economic Community (AEC) Blueprint 2025 that was ratified by ASEAN Leaders in 2016, which prioritise new strategic actions in building among other things, highly integrated and cohesive economy. Because of that matter, AEC Blueprint 2025 is viewed as problematic and fundamentally flawed due to the lack of human rights as well as gender standpoint that are fundamental to universal regional unity. In fact, Dominguez (2019) believed that AEC Blueprint 2025 excludes transgender from the ASEAN integration discussion and from the notion of the 'ASEAN woman'.

Nevertheless, that does not mean ASEAN member states ignore the importance of protecting human rights. The establishment of ASEAN Inter-governmental Commission on Human Rights (AICHR) in 2009 for instance, serve the purpose and trusted to become regional co-operation on human rights in the member states to deliver preliminary ground in the long run target of developing an efficacious promotional as well as protective human rights device for ASEAN people (Phan, 2019). It is worth mentioning that instead of being independent, the 
Commission is an inter-state organisation wherein committee members act on behalf of their respective governments while the Chair of the Commission is the representative of the government holding the rotating Chairmanship of ASEAN (Articles 3 \& 5.9 AICHR 2009).

Though AICHR (2009) lack jurisdiction to investigate allegations on human rights abuses, perform monitoring visits, consider individual accusations and converse on human rights issues in any ASEAN member states (Phan, 2019), AICHR (2009) is mandated to draft an ASEAN Human Rights Declaration (AHDR) (2012) which was the most notable contribution in promoting human rights norms across the jurisdiction. The ADHR was endorsed by heads of ASEAN Member States on 28 November 2012. Legally, ADHR is not a treaty, but since it is passed by the ASEAN Summit - 'the highest decision-making organ of ASEAN,' and pursuant to the ASEAN Charter, all ASEAN Summit decisions are anticipated to be enforced by appropriate ASEAN bodies and shall be considered as valid. However, Article 4 ADHR does not include the rights of transgender people. Notwithstanding the inadequacy of particular provisions on the rights of transgender people, the ADHR does stress that the rights of vulnerable and marginalised groups are an indefeasible, comprehensive as well as inseparable part of human rights and essential freedoms'. Still, Helen (2015) pointed out that AHRD lacks the capability to enforce its provisions in cases of transgression.

In additions, pursuant to Article 7 ADHR, the awareness of human rights have to be examined in the regional and state context taking into account diverse political, economic, legal, social, cultural, historical and religious backgrounds. In other words, the exercise of human rights and fundamental freedoms shall be subject only to such limitations as are determined by Article 8 ADHR.

A Regional Mapping Report on Trans Health, Rights and Development in Asia was produced to contribute information on the degree to which current health models and intervention are meeting the health needs of trans people in Asia (Asia Pacific Transgender Network, 2017). This report analyzed among others, the legality, availability and the accessibility of trans related healthcare services to the trans people in ASEAN countries which includes but not limited to general healthcare, gender affirming healthcare, hormones, sexual and reproductive healthcare services. Table 4 below specifies availability and the accessibility of trans related healthcare services to the trans people in ASEAN countries. 


\begin{tabular}{|c|c|c|c|c|c|}
\hline ASEAN Countries & $\begin{array}{l}\text { General } \\
\text { healthcare }\end{array}$ & $\begin{array}{l}\text { Gender } \\
\text { affirming } \\
\text { healthcare }\end{array}$ & Hormones & $\begin{array}{l}\text { Sexual and } \\
\text { reproductive } \\
\text { healthcare } \\
\text { services }\end{array}$ & $\begin{array}{l}\text { HIV in } \\
\text { community- } \\
\text { based } \\
\text { organizations }\end{array}$ \\
\hline Malaysia & $\checkmark(t w)$ & $\checkmark$ & $\checkmark$ & $\checkmark(\mathrm{tw})$ & $\checkmark(t w)$ \\
\hline Thailand & $x$ & $\checkmark$ & $\checkmark$ & $\checkmark(t w)$ & $\checkmark$ \\
\hline Indonesia & $\checkmark$ & $\checkmark$ & $\checkmark$ & $\checkmark(t w)$ & $\checkmark(t w)$ \\
\hline Philippines & $\checkmark$ & $\checkmark$ & $\checkmark(t w)$ & $\checkmark$ & $\checkmark$ \\
\hline Singapore & $\checkmark$ & $\checkmark$ & $\checkmark$ & $\checkmark$ & $\checkmark$ \\
\hline Myanmar & $x$ & $x$ & $\checkmark$ & $x$ & $\checkmark(t w)$ \\
\hline Vietnam & $x$ & $x$ & $\checkmark$ & $\checkmark(t w)$ & $\checkmark(t w)$ \\
\hline Laos & $\checkmark$ & $x$ & $\checkmark(t w)$ & $x$ & $V(t w)$ \\
\hline Cambodia & $\checkmark(\mathrm{tw})$ & $\mathrm{X}$ & $\checkmark(t w)$ & $V(t w)$ & $\checkmark(t w)$ \\
\hline
\end{tabular}

$(\mathrm{tw})=$ trans women

Table 4: Availability and the accessibility of trans related healthcare services to the trans people in ASEAN countries.

In general, most ASEAN countries are still left behind in providing such services. Even if they do, the services are selective in nature. In Cambodia for instance, most healthcare services such as general, sexual \& reproductive, hormones and HIV in community-based organizations (CBOs) are limited to trans women. The same applied to Indonesia whereas only the former is available to transgenders. Plus, unlike Indonesia, there is an absence of gender affirming healthcare services in Cambodia. In fact, Indonesia legally recognized such service while the legality of this service in Cambodia is not clear as there are no documents stating its legal status.

Perhaps, the best countries in providing trans related healthcare are Singapore and Philippine. Both countries offer almost all services to transgenders except for Philippines which is selective when producing hormones to trans women only. In additions, gender affirming healthcare services are legal in these countries. Myanmar however do not share common belief when it comes to provide trans related healthcare services. As a matter of fact, the only services available are HIV services in CBOs and hormones. Moreover, Myanmar considered gender affirming surgeries as a crime (Section 10, 312 b, c \& d Myanmar Penal Code).

\section{Findings}

In civil law perspective, Malaysia does not explicitly mention anything on transgender. The term 'indecent behaviour' under penal code is used to describe this action which holds individual to be fined up to MYR50.00. The small amount of penalty might not be a problem for some, but when it comes to registration, no individual is permitted to change his/her gender in his/her identification card unless errors were made, resulting to hurdles for transgender to enjoy similar rights other women/men can benefit. This is pursuant to Section 27 Malaysia Births and Deaths Registration Act and Section 6(2)(o) National Registration Act. Further, as of March 2021, there is no effort in ratifying ICCPR and ICESCR by Malaysia government. Looking on the bright side, when it comes to the availability and the accessibility 
of trans related healthcare services to the trans people, Malaysia offer almost all services to transgenders even though some services are selective to trans women only.

In Sharia law perspective however, it needs to be clear that Sharia law in Malaysia will not infringe on the rights of other religions. Muslim in Malaysia however face a penalty under state law from MYR1,000.00 to MYR5,000.00 or/and imprisonment up to three (3) years for appearing as women. It is noteworthy that no offense and punishment available under Malaysian Sharia law to women who appears as men except in the state of Sabah.

\section{Conclusion and Recommendation}

Needless to say, Malaysia is ridden by strong cultural, political, legal, and religious opposition to sexual minority rights to the extent makes the country to be one of the most transprejudiced country in the world. Undeniably, various efforts has been taken by numerous organisations to fight the right to non-discrimination towards transgender, but it often ended up receiving criticism from the society because of their majority Muslim people have strong regulations relating to the Islamic values (Sharia Law). Hence, the possibility to change or even intervene the local government to introduce policy prohibiting discrimination on the grounds of sexual orientation and gender identity can be difficult.

Muslims in Malaysia generally has no problem with ratifying any international human rights instruments conventions as long as it does not conflict with Federal Constitution. As a multi-racial and multi-religious country, Malaysians are pretty sensitive to any changes that threaten the position of Islam and indigenous privileges. In other words, certain restrictions and limitation still need to be adhered and they are usually based on Islamic values themselves. If it is contrary to Islamic or social values, than it will be opposed and any attempt to justify it is considered a war to Islam as the official religion of the federation. Not to mention, according to Malaysian culture, transgenderism violates two (2) 'National Principles of Malaysia' which are Rule of Law and Good Behaviour and Morality.

Despite the negative stigma against transgenderism, the number of transgender people is regardless increases in Malaysia. Statistical increase of transgender individuals leads to the same pattern in terms of the number of sexual transmitted diseases cases such as HIV and AIDS due to homosexual activities. This is a major reason as to why Shariah law strictly forbid transgender practice. However, it needs to be clear that there is no official definition of transgender in any Malaysia legislation. This loophole sparks question as to whether intersex individual is considered as a subset of transgender. Since Malaysia uphold Sharia law and Islamic value, perhaps there is path for intersex individual who according to Islamic jurists is not categorised as transgender, thus deserve to not be discriminated in all forms. Hence, the paper recommends Malaysian authority to endeavour to thoroughly define transgender from both civil and Sharia law point of view.

\section{References}

Afif, B. (2019). 'Islam and Transgender, (A Study of Hadith about Transgender).' International Journal of Nusantara Islam, 7(2): 185-198.

Al-Quran Karim, 42: 49-50.

Ar, Z. (2013). Seksualiti Merdeka organisers hope to outlast 'prejudicial' law. Malay Mail, 23 August. 
ASEAN Economic Community Blueprint 2025. (2015). Retrieved from https://asean.org/wpcontent/uploads/archive/5187-10.pdf [29 July 2019].

ASEAN Human Rights Declaration. (2012). Retrieved from https://www.asean.org/storage/images/ASEAN_RTK_2014/6_AHRD_Booklet.pdf [13 July 2019]

ASEAN Intergovernmental Commission on Human Rights Terms of Reference. (2009) Retrieved from https://www.asean.org/storage/images/archive/publications/TOR-of-AICHR.pdf [13 July 2019]

Asia Pacific Transgender Network. (2017). Regional Mapping Report on Trans Health, Rights and Development in Asia. Retrieved from https://weareaptn.org/2020/10/31/the-asiapacific-transgender-network-biennial-report-2017-2018/ [10 January 2021].

Battal, I., Khalaf, A. (2003/1423H). Sharh Sahih al-Bukhari. Al-Riyadh: Maktabah alRushd.

Bernama. (2018). Malaysia not ratifying UN human rights treaty. The Straits Times. https://www.straitstimes.com/asia/se-asia/malaysia-not-ratifying-un-human-rightstreaty

Bernama. (2019). In Muslim Malaysia, uproar over LGBT groups at Women's Day march. The Straits Times.

https://www.straitstimes.com/asia/se-asia/in-muslim-malaysia-uproar-over-lgbtgroups-at-womens-day-march

Births and Deaths Registration Act. (Malaysia).

Currah P., Minter, S., \& Green, J. (2013). Transgender Equality: A Handbook For Activists and Policymakers. Retrieved from http://www.nclrights.org/wpcontent/uploads/2013/07/transeq.pdf [8 November 2019].

Dermawan, A. (2018) .Bilangan gay, transgender semakin meningkat: JAKIM. Berita Harian, 29 Oktober.

Dominguez, M. (2019). Women and the ASEAN 2025: Locating the Gender and Human Rights Dimension of the ASEAN Economic Community (AEC). Retrieved from http://shapesea.com/wp-content/uploads/2019/07/7-Myrna.AcademicPaper.edited.pdf [8 November 2019].

Federal Constitution (Malaysia).

Gender Equality Act Gender Equality Act of B.E. 2558 (2015) (Thailand).

Gerber, P., \& Gory, J. (2014). 'The UN Human Rights Committee and LGBT Rights: What is it Doing? What Could it be Doing?'. Human Rights Law Review. 14(3): 403-439.

Gibson, B. A., Brown, S. E., Rutledge, R., Wickersham, J. A., Kamarulzaman, A., \& Altice, F. L. (2016). 'Gender identity, healthcare access, and risk reduction among Malaysia's mak nyah community,' Global Public Health.11(7-8):1011-1025.

Haniff, W. A. A. W., Hakimah, A., Ismail, R. (2019). The Regulation of Equity Crowdfunding in Malaysia and United Kingdom. Academic Journal of Interdisciplinary Studies, 8(3): 45-56.

Harper, G. W., Serrano, P. A., Bruce, D., \& Baurmeister, J. A. (2015). The Internet's Multiples Roles in Facilitating the Sexual Orientation Identity Development of Gay and Bisexual Male Adolescents. SAGE , 1-18

Helen, Q. (2015). The significance of an evolving relationship: ASEAN and the global human rights mechanisms. Human Rights Law Review, 15(1): 283-311. 
Hilmi, E. E., Salleh, K., \& Rahman, N. F. A. (2019). 'Isu-Isu Pluralisme Agama dalam Tuntutan Comango: Satu Analisis Terhadap Laporan 2013 dan 2018. International Journal of Islamic Thought. 15(June): 35-43.

Human Rights Committee. (2017). Concluding observations regarding Thailand. (CCPR/C/THA/2). file://Users/User/Downloads/G1709990.pdf [12 November 2019].

Human Rights Committee. (2019). Concluding observations regarding Vietnam. (CCPR/C/VNM/3). file:///Users/User/Downloads/G1925752.pdf [12 November 2019].

Human Rights Committee. (2018). Concluding observations regarding Lao People's Democratic Republic. (CCPR/C/LAO/1). file:///Users/User/Downloads/G1834738.pdf [12 November 2019].

Index Mundi. (2018). Malaysia Demographics Profile 2018. https://www.indexmundi.com/malaysia/demographics_profile.html [(8 November 2019].

Kambol, R. (2020). 'Kesalahan lelaki berpakaian wanita atau menyerupai wanita (tasyabbuh): isu dan cadangan penyelesaian.' Journal of Law \& Governance. 3(1):113-126.

Khuhro, R. A., \& Ahtisham, M. (2020). 'Social media usage patterns among transgender people of Hyderabad, Sindh, Pakistan.' International Journal of Media and Information Literacy, 5(1):37-47.

Loshana, K., Shagar., Zainal, F., \& Loh, A. (2018). Portraits of LGBT activists taken. The Star Online, 9 August.

Malaysia Department of Statistic. (2019). Demographic Statistics Second Quarter, 2019, Retrieved from

Malaysia.https://www.dosm.gov.my/v1/index.php?r=column/cthemeByCat\&cat $=43$ 0\&bul_id=VTJDdStOakJJd2EwcEVVTm4yRDZSQT09\&menu_id=LOpheU43NWJwRWVS ZkIWdzQ4TIhUUT09 [8 November 2019].

Malaysia Mufti of Federal Territory. (2015). Siri 5 : Isu Transgender, Tasyabbuh Atau Penyerupaan: Hukumnya (Edisi Kemaskini). Retrieved from https://muftiwp.gov.my/ms/artikel/bayan-linnas/1820-siri-5-isu-transgendertasyabbuh-atau-penyerupaan-hukumnya-edisi-kemaskini [8 November 2019].

Malaysia Mufti of Federal Territory. (2017). Irsyad Al- Fatwa Ke- 202: Hukum Hakam Berkaitan Khunsa. Retrieved from https://muftiwp.gov.my/ms/artikel/irsyadfatwa/irsyad-fatwa-umum/751-irsyad-al-fatwa-ke-202-hukum-hakam-berkaitankhunsa [12 November 2019].

Minor Offences Act (1955). Malaysia.

Mohamad, M. (2015). 'Lesbian, Gay, Bisexual and Transgender: A Syariah Criminal Law Perspective.' Jurnal Undang-undang dan Masyarakat.19:29-36.

National Registration Act. (Malaysia).

Nurhidayatuloh, N., Febrian, F. (2019). 'ASEAN And European Human Rights Mechanisms, What Should Be Improved?' Journal of Law. 6(1): 151-167.

Park, A., \& Mendos, L.R. (2019). FOR ALL: The Sustainable Development Goals and LGBTI People. Retrieved from https://www.researchgate.net/publication/331998586_FOR_ALL_The_Sustainable_ Development_Goals_and_LGBTI_People [8 November 2019].

Peletz, Michael G. (2006). Transgenderism and Gender Pluralism in Southeast Asia since 
Early Modern Times, 47(2). The University of Chicago Press.

Penal Code (Malaysia).

Penal Code (Myanmar).

Phan, H. D. (2019). 'Promotional versus protective design: the case of the Asean intergovernmental commission on human rights.' The International Journal of Human Rights.23(6): 915-937.

Sharia Courts (Criminal Jurisdiction) Act 1965 (Revised 1988) (Malaysia).

Sharia Criminal Offences (Federal Territories) Act 1997 (Malaysia)

Tahmindjis, P. (2005). 'Sexuality and international human rights law.' Journal of Homosexuality, 48(3/4): 9-29.

The United Nations General Assembly. (1966). International Covenant on Civil and Political Rights. Treaty Series, 999,171.

The United Nations General Assembly. (1966). International Covenant on Economic, Social, and Cultural Rights. Treaty Series, 999, 171.

UNAIDS. (2014). Guidance note: Services for transgender people. http://www. unaids.org/sites/default/files/media_asset/2014unaidsguidancenote_servicesfortran sge nderpeople_en. [8 November 2019].

UNDP, MSDHS (2018). Legal Gender Recognition in Thailand: A Legal and Policy Review. file:///Users/User/Downloads/legal-gender-recognition-in-thailand-2018.pdf [1 January 2021].

United Nations. (2016). Ban calls for efforts to secure equal rights for LGBT community. https://www.un.org/sustainabledevelopment/blog/2016/09/ban-calls-for-efforts-tosecure-equal-rights-for-lgbt-community/ [8 November 2019].

United Nations. (1948). Universal Declaration of Human Rights. https://www.ohchr.org/en/udhr/documents/udhr_translations/eng.pdf [18 November2019].

Vijay, A., Earnshaw, V. A., Tee, Y. C., Pillai, V., Hughto, J. M. W., Clark., Kamarulzaman, A., Altice. F. L., Wickersham. J. A. (2018). 'Factors Associated with Medical Doctors' Intentions to Discriminate Against Transgender Patients in Kuala Lumpur, Malaysia.' LGBT Health. 5(1):61-68.

Wickersham, J. A. (2017). 'Prevalence of Human Immunodeficiency Virus and Sexually Transmitted Infections Among Cisgender and Transgender Women Sex Workers in Greater Kuala Lumpur, Malaysia: Results From a Respondent-Driven Sampling Study'. Sexual Transmitted Disease. 44(11): 663-670.

Winter, S. (2009). 'Cultural Considerations for the World Professional Association for Transgender Health's Standards of Care: The Asian Perspective. International Journal of Transgenderism. 11(1):19-41. 